\title{
Ethical Life Redefined in Jonathan Safran Foer's Eating Animals
}

\author{
Jonathan Safran Foer'in Hayvanları Yemek Adlı Eserinde Yeniden \\ Tanımlanan Etik Yaşam
}

\begin{abstract}
Işıll ÖZCAN*
Abstract: This study analyzes the young American novelist Jonathan Safran Foer's astounding work of creative nonfiction Eating Animals (2009) from two ethical frameworks. First, Foer demonstrates contemporary American creative nonfiction's propensity for ethical reflection and dedication to the forceful investigation of the disregarded and dismissed aspects of our daily moral existence, and demonstrates the sheer amount of research as well as intellectual bearing that such reflection requires. Second, inasmuch as Eating Animals is a study in/of ethics, it also presents new vistas for the recent "ethical turn" in literary studies whose theoretical focus remains limited to the study of the novel. Through a close reading of Eating Animals for its avowed ethical stance and its enriching contribution in the mode of a transfigured reenactment of the current (re)turn to ethics within literary studies, this study bears witness to a new direction in contemporary American literature that draws its force from contemporary creative nonfiction's increasing proclivity for truthful and ethical storytelling.
\end{abstract}

Keywords: Jonathan Safran Foer, Eating Animals, creative nonfiction, the ethical turn, storytelling

Öz: Bu çalışma genç kuşak Amerikan romancılarından Jonathan Safran Foer'ın Hayvanları Yemek (2009) adlı kurmaca-dışı eserini iki etik çerçevede inceler. İlk olarak, Foer çağdaş Amerikan kurmaca-dışı yazınının etik düşünme potansiyelini ortaya çıkarıp gündelik ahlaki varoluşumuzun yok sayılan ve önemsenmeyen yönlerini inceler ve bu etik düşünme şeklinin gereksinim duyduğu derinlemesine araştırmanın ve entelektüel yaklaşımın önemini vurgular. İkinci olarak, Hayvanları Yemek kendi başına etik bir girişim olmakla beraber, edebiyat çalışmalarında son zamanlarda ortaya çıkan ve teorik çerçevesi roman incelemeleriyle sınırlı kalan “etik dönüş” akımına yeni ufuklar açar. Hayvanları Yemek'in etik duruşunun detaylı bir okumasını yapan ve eserin güncel etik edebiyat eleştirisini zenginleştiren katkılarını tartışan bu çalışma, çağdaş Amerikan edebiyatında kurmaca-dışı türünün hakikate dayalı ve etik hikâye anlatımı ile ortaya çıkan yeni bir yönelimi tartışmaya açar.

Anahtar sözcükler: Jonathan Safran Foer, Hayvanları Yemek, kurmaca-dışı, etik dönüş, hikâye anlatımı

\section{Introduction}

Jonathan Safran Foer (b. 1977), is one of the preeminent contemporary American novelists, who offers a groundbreaking work of nonfiction in Eating Animals (2009) that seems to necessitate a revision, first, of the nonfiction genre, and second, of the recent 'ethical turn' in literary studies. In Foer's tour de force, nonfiction is deployed deliberately to redefine the ethics of storytelling;

\footnotetext{
* PhD. Res. Assist., Dokuz Eylül University, Faculty of Letters, American Culture and Literature Department, İzmir, isil.ozcan@deu.edu.tr

This study is part of the author's doctoral thesis titled Beyond Irony: The Cult of Sophistication in Contemporary American Literature, which was supported by DEU BAP No: 2009.KB.SOS.009.
} 
Eating Animals crowns truthfulness and ethical reflection as the twin pillars of storytelling in nonfiction's fact-based narrative. Meanwhile, Foer posits both the act of storytelling itself and responding to that act as the other that we have to encounter and respond to ethically. Moreover, the enlightening ethical perspective in Eating Animals is amplified in the way this work resonates with a current trend in literary studies, that is, the so-called ethical turn. However, this resonation seems to be as much a contribution to it as it is a revision, or better yet, a necessary but belated reconsideration, of the place of nonfiction in contemporary literary studies in general and in ethical literary criticism in particular.

\section{Ethics in Literary Study}

Traditionally, ethics means the philosophical investigation of right conduct and the study of the obligations for a good life. Literature, if it is one of our most reliable sources for understanding and investigating life and human existence, could never operate without ethics. However, the seeming inseparability of ethics and literature and the organized study of this relation have been contested within literary studies since the 1980s by poststructuralist/postmodern theory for various reasons such as naiveté, pious moralism, and superficiality. Both in response to such reduction and for other reasons, a literary movement, christened the 'ethical turn,' has burgeoned to restore and reinvigorate the legitimate study of the relationship between literature and ethics from the late 1990s, becoming, in a way, the last of the many turns that seem to characterize the late twentieth and early twenty-first centuries the linguistic turn, the cultural turn, the postmodern turn, and the pragmatist turn. The origins of the origins of the ethical turn are contested. Deconstructionists and literary theorists in general consider the revival of interest in ethics as a positive outcome of the democratic and non-marginalizing attitude of postmodernism and it is believed that "[t]he decentering of the subject has brought about a recentering of the ethical" (Garber et al., 2000, viii-ix). Traditional humanists, in contrast, posit that ethical criticism has regained in prestige now that its nemesis, that is, theory, has lost its thirty-year reign. Meanwhile, moral philosophers increasingly privilege the novel as the most fruitful and insightful arena for ethical reflection if not the natural subject matter of moral philosophy. However, referring to the popularity of ethics during the 1990s, Lawrence Buell succinctly observes that "[a]s with any groundswell, particularly when the central term of reference already belongs to common usage, the challenge of pinning down what counts as ethics intensifies as more parties lay claim to it" (Buell, 1999, 7).

Nonetheless, it is possible to speak of two landmark events regarding the emergence of the ethical turn in literary studies. First, in 1983, New Literary History published "a pioneering special issue", Literature and/as Moral Philosophy, and the affair between ethics and literature goes "public" (Eskin, 2004, 558). This issue carried influential moral philosophers such as Martha C. Nussbaum, Cora Diamond, and Hilary Putnam discussing the relevance of the study of the novel to moral philosophy and Nussbaum's groundbreaking essay on James's The Golden Bowla working manifesto essay which in many ways establishes the grounds for the moral philosopher's turn to the novel for ethical reflection and comprises an excellent example of the shape such a turn would take. Second, in 1987, the American deconstructionist Paul de Man's anti-Semitic journalism was discovered and in the Woolfian pun of Geoffrey Galt Harpham, "[o]n or about December 1, 1987, the nature of literary theory changed" (Harpham, 1995, 389). Since then, compelled to prove that deconstruction is and has always been ethically and socially committed, "literary theorists allied with deconstruction have taken a marked turn toward the ethical" (Nussbaum, 1990, 29). This is not to say that it is only deconstructionists who have turned to ethics; in Dorothy J. Hale's words, "[s]ince the turn of the new century, there has been an 
increasing return to ethical inquiry staged by literary critics" (Hale, 2007, 188).

The ethical turn can be seen, on the one hand, as a revival of traditional ethics with a focus on a refreshed concept of intersubjectivity between reader and writer, and on the other, as the (mostly retrospective) re-assessment of poststructuralist and/or postmodern theory in the mode of proving its ethical concerns. In the latter case, the character of the turn may seem somewhat paradoxical. As Beverly R. Voloshin explains, ethics has been subject to the "corrosive critique" of postmodern philosophy because it was considered another humanist metanarrative (Voloshin, 1998, 69). However, the "skeptical energies of postmodern critique" enabled "a counter-movement within postmodern philosophy to establish an ethics compatible with postmodern philosophy's suspicion about positive or universal claims drawn from the standards of reason, nature, and law" (Voloshin, 1998, 69). As Jennifer Geddes puts it,

[b]y exposing the cracks in seemingly comprehensive totalities and reading authoritative texts against themselves, postmodernism's critiques created space in which previously marginalized and silenced voices were able to speak. What these voices had to say brought to scholars' attention a whole range of ethical issues, experiences of suffering, and aspects of human experience (including the religious) that had previously not garnered attention. Interestingly, these revelations called for ways of thinking, reading, and responding that exposed the limitations of postmodernism's approaches. In other words, the very delegitimizing of grand narratives by postmodern thought opened up space that allowed and encouraged the particular narratives of those not in power to be told and heard, but that in doing so, this "delegitimizing" gesture has brought forth narratives that describe, express, and protest a range of suffering, injustice, and evil that postmodernism has been ill equipped to respond to-hence its turn to questions of ethics, suffering, and religion (Geddes, 2007, 72-73).

On the matter of postmodernism, it should be noted that one recent and very frequent argument regarding postmodernism considers its relation to ethical concerns. According to Todd F. Davis and Kenneth Womack, the high tide of theory (which they interchangeably call the poststructuralist era or postmodernity) is characterized by an aversion to any mention of ethical concerns or moral insights in literary studies. This seems "natural" considering the particular historical conjecture that has witnessed "the demise of modern humanism" after the world wars, nuclear weaponry, Auschwitz, as well as the biases of Anglocentrism and Eurocentrism in literary production (Davis, \& Womack, 2001, ix). Nevertheless, "to pretend that the ethical or moral dimensions of the human condition were abandoned or obliterated in the shift to postmodernity certainly seems naïve" (Davis and Womack, 2001, ix). Part of the reason for such a misunderstanding is postmodernity's resistance to "the simplistic, uncomplicated prescription of external ethical forces regarding so many different literatures and cultures" (Davis, \& Womack, 2001, x). For Davis and Womack, the recent turn to ethics in contemporary literary scholarship can best be characterized as the refusal "to return to a dogmatically prescriptive or doctrinaire form of reading" (Davis, \& Womack, 2001, x). Rather than such return, "ethical criticism appears to be moving, in all its various forms, toward a descriptive mode, a dialogue between what has occurred in the past and what is alive and in process at the present" (Davis, \& Womack, 2001, x).

As for humanist critics like Wayne Booth, Daniel Schwarz, and David Parker, the ethical 
turn re-validates literature's moral insight and importance in the face of literary theory that has decentralized almost everything that is essential to their ideas of literature: free agents, traditions, and common values. Their attitude is one of harsh reaction to theory and the interest in ethics takes the form not of changing priorities and developments in literary theory but of a retaliation against theory. Their arguments are straightforward; for Schwarz, reading ethically is an intrinsic part of, or life-long duty in, human life because "we never take a moral holiday from our values," neither in reading nor in life, and "we can no more ignore the ethical implications of what we read than we can ignore the ethical implications of life" (Schwarz, 2001, 5). Ethical criticism, in this account, owes its power to literature's vitality: "our reading experience, if we read actively and with intelligence, is central to life and contributes to the development of the mature personality" (Schwarz, 1997, 191). In the process of reading, "human readers respond to human subjects presented by human authors within an imagined world that represents-even if only as an illuminating distortion-anterior reality" (Schwarz, 1997, 192). Inevitably, humanist ethical criticism "sees literature as providing surrogate experiences for the reader, experiences which, because they are embodied within artistically shaped ontologies, heighten our awareness of moral discrimination" (Schwarz, 1997, 191).

Similarly, in his authoritative book The Company We Keep, Wayne Booth asserts that reading ethically is one of the "most important cultural 'assignments" for readers, writers, and critics alike (Booth, 1988, 227). If we can talk and write about the ethical value of stories, narratives, and fictions, we shall be able to talk equally responsibly about life itself. For Booth, the importance of ethical criticism lies, above all things, in its subject matter: story. Story has existed since "the beginning," and it is through story that "human beings were created and now continue to recreate themselves" (Booth, 1988, 39). We make sense of every mundane event, each "primary experience-that is, events like birth, copulation, death, plowing and planting, getting and spending" through "some sort of mediation in narrative" (Booth, 1988, 14). However, the move from the experience of an event to its narration "is so automatic and frequent that we risk losing our sense of just how astonishing our story worlds are, in their power to add 'life' upon 'life'-for good or ill" (Booth, 1988, 14). That is to say, "we live more or less in stories," and it is sometimes difficult to "resist surrendering to what is 'only" imaginary" (Booth, 1988, 14-15). The noticeably permeable boundary 'between life and narrative' along with narrative's inevitable influence on us establishes fiction as 'the most powerful of all the architects of our souls and societies' (Booth, 1988, 16, 39). In other words, for Booth, we are storied selves finding our essence as well as "standards of truth, relevance, and spiritual depth" in stories (Booth, 1988, 347). Indeed, one of the most important arguments of The Company We Keep is Booth's determinacy "to restore the full intellectual legitimacy of our commonsense inclination to talk about stories in ethical terms, treating the characters in them and their makers as more like people than labyrinths, enigmas, or textual puzzles to be deciphered" (Booth, 1988, x).

What is most interesting about the recent interest in ethical literary criticism is that it goes beyond fostering the long held belief of literature's role in moral formation and education. Some of the recent endeavors in ethical criticism hold that the text is an other that the reader is required to respond responsibly. Further, they investigate the kinds of narrative choices stylistic and narrational the author makes and the ways in which they inform our ethical judgments. Nevertheless, it is possible to say that the ethical turn is a collective effort that has produced surprisingly disparate approaches and methodologies. Thinkers across disciplines and schools have put forward the necessity of a renewed concern for the ethical in literary studies which has either somehow undermined the relevance of ethics due to a theoretical focus or simply mistook 
ethics for the political.

\section{The Status of Nonfiction in Ethical Literary Criticism}

Something inevitably goes astray in these discussions and the (theoretical) effort to define the ethical in literary studies casts a shadow over the practice of ethics in literature. Indeed, one major shortcoming crystallizes here: literature, seemingly deployed as an umbrella term, ends up referring exclusively to the novel. In addition, nonfiction's endeavors of storytelling are ignored if not rendered both ethically and literarily less important. Although Booth's emphasis on the ethically formative effects of stories, postmodern or poststructuralists' emphasis on nondoctrinaire reading, and deconstruction's take on the text as the other altogether offer a refreshed look on ethical criticism, the function and use of the term literature seems to be reduced to its imaginative powers. In order to assess the unintentional hazards of such exclusionary logic, the discussion moves on to a close reading of Foer's Eating Animals in an essentially non-exclusionary manner that aims at demonstrating the enabling possibilities of the ethics of nonfictional storytelling.

Contrary to the prejudices it might initially generate, Eating Animals is not a defense of, or propaganda for, vegetarianism. It is rather, like Sinclair Lewis's scandalizing novel The Jungle of a century ago, an exploration of the underbelly of meat production, hence a sociopolitical exposé. Hence, it is possible to consider Eating Animals a work that updates the nineteenth century practice of muckraking albeit with a heightened literary sensibility of the ethical treatment of factuality. That is to say, the ethical force of Eating Animals intensifies through the writer's own ethical encounter with his subject, through his merging of responsible storytelling and truth-telling. Foer cannot conduct interviews with animals, but looks at them in the face, and in the Levinasian sense of face-to-face encounter, the ethical relationship takes place at the instant of such encounter. Therefore, it is in the sense that Foer relies on the investigative journalism of muckrakers but moves toward a discussion of the human in its ethical bearing that his book deserves elaboration as an ethically charged work of nonfiction.

Before writing this book, Foer spent a year reading all the literature he could find on "eating animals: histories of agriculture, industry and United States Department of Agriculture materials, activist pamphlets, relevant philosophical works, and the numerous existing books about food that touch on the subject of meat" (Foer, 2009, 45). He then began paying extensive visits to factory farms, leart the minutest details about the conditions animals are kept in factory farms. He even includes a life-size rectangle that an egg-laying hen is typically allowed to stand on all through its short course of life, which is quite smaller than the actual page these words are written on. Foer also visited some of the few remaining family farms and reserves individual chapters for the farmers' stories. The reports from his investigations form the middle of the book. At the end, Foer presents a detailed, sixty-page Notes sections and an Index.

Eating Animals begins by establishing the role of food in human life. Foer grows up in a crowded Jewish family that often gathers at his grandmother's house for meals. His grandmother is an excellent cook, but she always cooks "chicken with carrots," and nobody ever gets tired of eating this "delicious" dish (Foer, 2009, 4). While they eat, his grandmother rarely sits with them. "Even when there was nothing more to be done, she stayed in the kitchen, like a vigilant guard (or prisoner) in a tower. [... As if] the sustenance she got from the food she made didn't require her to eat it" (Foer, 2009, 3). When she is not cooking and serving, she tells her grandchildren facts about food: "dark food is inherently healthier than light food, or that most of the nutrients are found in the peel or the crust. [...] No foods are bad for you. Fats are healthy-all fats, always, in any quantity. Sugars are very healthy. The fatter the child is, the healthier it is" 
(Foer, 2009, 4). His grandmother's stories about food, however, are also the story of her life.

Foer presents us with a parable both a fact and a story based on his grandmother's childhood experiences. She escapes from Poland during World War II. Foer tells us, "[m]y grandmother survived the War barefoot, scavenging other people's inedibles: rotting potatoes, discarded strips of meat, skins, and the bits that clung to bones and pits" (Foer, 2009, 3). In other words, during the war, she is a homeless, wandering child, always in mortal danger, always tired, always hungry. Once, when a lot people have died from starvation, a Russian farmer pities her and gives her a piece of meat, yet the hungry child nearing death won't eat the meat to save her life, because the meat is pork, not kosher. Foer asks his grandmother, "[b]ut not even to save your life?" to which she replies, "[i]f nothing matters, there's nothing to save" (Foer, 2009, 17). This answer is a clue to Foer's ethical investigation in Eating Animals. If a person does not have a self with ethical principles, and if storytelling does not carry that message through time, there is nothing of human value there to save.

Therefore, Foer discovers as a child that for his Jewish grandmother, food was "not food. It [was] terror, dignity, gratitude, vengeance, joyfulness, humiliation, religion, history, and, of course, love" (Foer, 2009, 5). Put differently, food was, for his grandmother, life, death, family, metaphysics, war, ethics, a story of the past, and of the future. As Foer perceives his grandmother's understanding of food, he understands that food is both duty and ecstasy, both crude matter and transcendence. According to Foer, "stories about food are stories about us-our history and our values" (Foer, 2009, 11). He means that what and how we eat, and the stories we tell about eating are constitutive of who we are in terms of our values. "Within my family's Jewish tradition," Foer explains, "I came to learn that food serves two parallel purposes: it nourishes and it helps you remember. Eating and storytelling are inseparable-the saltwater is also tears; the honey not only tastes sweet, but makes us think of sweetness" (Foer, 2009, 1112). "We are made of stories," he concludes, and our stories about the meanings of our choice of food turn the act of eating into a realm of values, because, as Foer wonders, " $[w]$ hy should eating be different from any of the other ethical realms of our lives?" (Foer, 2009, 14, 9).

Accordingly, Eating Animals begins and ends with chapters titled "Storytelling". This gives the book a circular structure: it begins with stories and ends with stories. In this way, Foer shows that nonfiction is as much a narrative as it is a collection of facts. As we noted above, Foer's researches and reports make up the middle of the book. As he literally surrounds the factual with the story, or storytelling, he reminds us, like Booth, that we give meaning to our world and our lives through storytelling, which, of course, is a way of constructing our world and our selves. The stories end up shaping our future as well as our past because our notion of reality is formed through our stories; the plausibility of our stories marks us as realists. Foer thinks as much about his childhood stories about food as about the ones he will tell his children. He wants to tell his offspring good stories; meaningful and morally valid stories. He thinks that we are as ethical as our desire and ability to take responsibility for our stories hence Eating Animals' concern with meat as food. Therefore, he demonstrates how our thoughts and actions are, to the extent that they construct and represent our sense of reality, integral pieces of our story. For Foer, the most basic modes of our existence are the most revealing elements of the stories that make us who we are. In other words, the human self is composed of its stories.

The originating impulse behind Eating Animals is Foer's fatherhood. He explains, "[f]eeding my child is not like feeding myself: it matters more. It matters because food matters (his physical health matters, the pleasure of eating matters), and because the stories that are served with food matter. These stories bind our family together. And bind our family to others" (Foer, 2009, 11). 
For instance, when a child learns that "the parsley on the plate is for decoration, that pasta is not 'breakfast food,' we eat wings but not eyes, cows but not dogs", we pass this information with stories which "establish narratives, and stories establish rules" (Foer, 2009, 12). A surprisingly rich set of codes and values pass on to the next generation in stories about food.

As a person, a father, a citizen, and a writer, Foer decides to face a reality that is quite basic: do we know exactly how our food is produced? Do we have any real knowledge and control of what we eat? Foer explains,

[t]his story didn't begin as a book. I simply wanted to know-for myself and my family-what meat is. I wanted to know as concretely as possible. Where does it come from? How is it produced? How are animals treated, and to what extent does that matter? What are the economic, social, and environmental effects of eating animals? My personal quest didn't stay that way for long. Through my efforts as a parent, I came face-to-face with realities that as a citizen I couldn't ignore, and as a writer I couldn't keep to myself. But facing those realities and writing responsibly about them are not the same (Foer, 2009, 12).

An attempt to define what meat is, therefore, even for those who unconsciously avoid the topic religiously, is uncomfortable to say the least. The topic of eating animals "cuts right to one's deepest discomforts, often provoking defensiveness and aggression" (Foer, 2009, 13). Foer wonders, if we assume for a moment that extremely evil things are indeed done in order to supply us with meat, should this fact be "ethically compelling" for us? (Foer, 2009, 14). Should we feel sympathy for animals in order to care about our meat? As for Foer's personal story with respect to animals, until he was twenty-six he dislikes animals; he found them "bothersome, dirty, unapproachably foreign, frighteningly unpredictable, and plain old unnecessary" (Foer, 2009, 21). His particular dislike of dogs (he thinks) was based on a "fear that [he] inherited from [his] mother, which she inherited from [his] grandmother" (Foer, 2009, 21). The inherited fear and dislike persists until he sees a stray puppy while strolling in Brooklyn, and adopts her (named George) on the spot. Foer suddenly becomes, in his words, "a dog person" (Foer, 2009, 21). He believes that the major issue in liking and disliking animals is how we feel about encountering the other because, on a basic level, interacting with animals is not essentially different from interacting with people:

Our various struggles to communicate, to recognize and accommodate each other's desires, simply to coexist force me to encounter and interact with something, or rather someone, entirely other. George can respond to a handful of words (and choose to ignore a slightly larger handful), but our relationship takes place almost entirely outside of language. She seems to have thought and emotions. Sometimes I think I understand them, but often I don't. [...] The list of our differences could fill a book, but like me, George fears pain, seeks pleasure, and craves not just food and play, but companionship. I don't need to know the details of her moods and preferences to know that she has them. Our psychologies are not the same or similar, but each of us has a perspective, a way of processing and experiencing the world that is intrinsic and unique. I wouldn't eat George, because she's mine. But why wouldn't I eat a dog I'd never met? Or more to the point, what justification might I have for sparing dogs but eating other animals? (Foer, 2009, 23-24). 
The question of "other animals" that are eaten is highly disturbing. The great majority of animal production for human consumption in the U.S. is done in factory farms. "Ninety-nine percent of all land animals eaten or used to produce milk and eggs in the United States are factory farmed. So although there are important exceptions, to speak about eating animals today is to speak about factory farming" (Foer, 2009, 34). Simply put, factory farming is "industrialized" largescale "agriculture" where animals are "genetically engineered, restricted in mobility, and fed unnatural diets (which almost always include various drugs, like antimicrobials)" (Foer, 2009, 34). Although considered to be economically viable, factory farming disregards issues like "environmental degradation, human disease, and animal suffering" (Foer, 2009, 34). In this way, factory farming completely reverses the traditional understanding of farming: "For thousands of years, farmers took their cues from natural processes. Factory farming considers nature an obstacle to be overcome" (Foer, 2009, 34). In terms of encountering the other, factory farming encounters nature, animals, and behaves utterly irresponsible. Yet at the same time knows how to convey the opposite impression and addresses the "consumers" nostalgic images of food production the fisherman reeling in fish, the pig farmer knowing each of his pigs as individuals, the turkey rancher watching beaks break through eggs because these images correspond to something we respect and trust (Foer, 2009, 35). Besides respect and trust, eating animals is connected to other significant feelings and moral terms, such as shame, being realistic and sentimental.

Foer elaborates on the role of shame in our relationship with animals by referring to Franz Kafka and Jacques Derrida. First, Foer refers to Max Brod's anecdote about Kafka's vegetarianism. While visiting the great aquarium in Berlin, Kafka, who has just become a vegetarian, looks at the fish in tanks and remarks, "[n]ow at least I can look at you in peace, I don't eat you anymore" (qtd. in Foer, 2009, 36). Therefore, Foer thinks that behind Kafka's vegetarianism is the underlying shame he felt in front of animals while he was eating them: shame, "the core experience of the ethical," is both "social" shame, directed toward "invisible others," and "intimate" shame springing deep from within our minds and hearts (Foer, 2009, 36). Foer believes that shame is also connected to forgetting:

Shame is what we feel when we almost entirely forget social expectations and our obligations to others in favor of our immediate gratification. Fish, for Kafka, must have been the very flesh of forgetting: their lives are forgotten in a radical manner that is much less common in our thinking about farmed land animals. Beyond this literal forgetting of animals by eating them, animal bodies were, for Kafka, burdened with the forgetting of all those parts of ourselves we want to forget. If we wish to disavow a part of our nature, we call it our "animal nature." We then repress or conceal that nature, and yet, as Kafka knew better than most, we sometimes wake up and find ourselves, still, only animals. [...] We can recognize parts of ourselves in fish-spines, pain receptors but then deny that these animal similarities matter, and thus equally deny important parts of our humanity. What we forget about animals we begin to forget about ourselves. Today, at stake in the question of eating animals is not only our basic ability to respond to sentient life, but our ability to respond to parts of our own (animal) being. There is a war not only between us and them, but between us and us. It is a war as old as story and more unbalanced than at any point in history (Foer, 2009, 37). 
Therefore, just like "taste," "shame" is both intimate and social; insofar as it shows how responsible we feel before the other. In abusing, mistreating, disrespecting, terrorizing, killing, and eating animals, we "forget" their lives. But this is not all. According to Kafka, animal bodies carry all those things in ourselves that we would like to forget. "Animal nature" is what we conceal (Foer, 2009, 37).

Foer juxtaposes Kafka's sense of shame with Derrida's claim in The Animal that Therefore I Am that "[t]he animal looks at us, and we are naked before it" (qtd. in Foer, 2009, 38). When an animal appeals to us, solicits us, we are "exposed," we have been "called" in a way (Foer, 2009, 38). There is an ethical interrogation of us in the look of an animal. Foer, when he comes face to face with the sea horses in the Berlin aquarium, which are a significant "bycatch" of tuna fishing all over the world, feels shame "in being human" (Foer, 2009, 40). He writes, "I felt shame in the deaths my culture justified by so thin a concern as the taste of canned tuna" (Foer, 2009 , 40). Both his son and his dog, George, call Foer to shame and responsibility on the matter of the eating of animals, just by looking into his eyes, in neutral appeal. As Foer explains,

nothing inspires as much shame as being a parent. Children confront us with our paradoxes and hypocrisies, and we are exposed. You need to find an answer for every why Why do we do this? Why don't we do that? and often there isn't a good one. So you say, simply, because. Or you tell a story that you know isn't true. And whether or not your face reddens, you blush. The shame of parenthood which is a good shame is that we want our children to be more whole than we are, to have satisfactory answers. My son not only inspired me reconsider what kind of eating animal I would be, but shamed me into reconsideration. And then there's George, asleep at my feet while I type these words. [...] Sometimes she'll wake from a dream panting, jump to her feet, get right up near me her hot breath pushing against my face and look directly into my eyes. Between us is ... what? (Foer, 2009, 40-41).

Between human and human as much as between human and animal, Foer suggests, is the same face-to-face encounter that initiates, or necessitates, ethical response to the other.

Besides shame, the other moral term that pervades the topic of eating animals is sentimentality. Habit, to the extent that it forms taste, desires, dislikes, actions, is also a story that sustains a self. Foer has established that factory farm companies like Tyson Foods, Kentucky Fried Chicken (KFC), ... etc. misrepresent the truth about meat production; the same holds true for government institutions that are in part funded by the corporations; even the language of reform in this area (free-range, fresh, organic, etc.) is riddled with lies. While there is a commercial story, and a bureaucratic story, about eating animals that controls the language on this topic, there are also other stories and languages such as the ancient notion of kosher, which compels us to kill animals humanely, to approach them with humility, and to cause no "unnecessary suffering," or the late modern position of People for the Ethical Treatment of Animals (PETA), which holds that "animals are not ours to eat, wear, experiment on, or use for entertainment" (Foer, 2009, 69, 72). Ironically, in daily language, those people who choose to act in accordance with majority values on animals and the environment by refusing to eat animals are called "marginal or even radical" (Foer, 2009, 74). This is at root the difference between being a sentimentalist or a realist: 
Is caring to know about the treatment of farmed animals a confrontation with the facts about the animals and ourselves or an avoidance of them? Is arguing that a sentiment of compassion should be given greater value than a cheaper burger (or having a burger at all) an expression of emotion and impulse or an engagement with reality and our moral intuitions?

Two friends are ordering lunch. One says, "I'm in the mood for a burger", and orders it. The other says, "I'm in the mood for a burger", but remembers that there are things more important to him than what he is in the mood for at any given moment, and orders something else. Who is the sentimentalist? (Foer, 2009, 74).

Foer's question compels us to think about the difference between a person who confronts the facts of animal/meat production and acts on it by changing his/her life, and another person who disregards animal mistreatment and allows his/her mood or taste to overrule reality and ethics.

Foer notes that the great writer Isaac Bashevis Singer, who escaped from Nazi occupation in Poland, compared the human bias against animals to Nazi racism. According to Singer, animal rights advocacy is based on the most basic, the purest form of social justice; animals are "the most vulnerable of all the downtrodden", and we have no right to consider our food preferences as more important than the fundamental and significant interests of animals-we cannot simply decide that their suffering does not matter (Foer, 2009, 213). For Singer, "mistreating animals [is] the epitome of the 'might-makes-right' moral paradigm" (Foer, 2009, 213). Moreover, given the fact that eating animals participates in an industrial system (factory farming) that is cruel, wasteful, and destructive of the environment, what can we do personally and communally? What is our ethical obligation? What if we knew that "animal agriculture makes a $40 \%$ greater contribution to global warming than all transportation in the world combined" (Foer, 2009, 43). Foer decides to become a vegetarian and to feed his child no product that is factory farmed. Next he proceeds to dream of newly-invented stories to replace our unethical, "animal forgetting" stories:

What kind of world would we create if three times a day we activated our compassion and reason as we sat down to eat, if we had the moral imagination and the pragmatic will to change our most fundamental act of consumption? Tolstoy famously argued that the existence of slaughterhouses and battlefields is linked. Okay, we don't fight wars because we eat meat, and some wars should be fought-which is not to mention that Hitler was a vegetarian. But compassion is a muscle that gets stronger with use, and the regular exercise of choosing kindness over cruelty would change us (Foer, 2009, 257-258).

In this sense, Foer questions the irrational primacy we give to our habits, the unethical, unquestioned, almost ungrounded basis of most of our tastes and likes and dislikes. Foer shows that we cannot present, neither to ourselves nor to others, our choice of food as based on taste, habit, and mood. We cannot present such choice as rational and therefore as something that cannot bear discussion. His point is that our irrational make-up of selves and our choices are precisely what must be questioned in a properly ethical self-examination. 'Take me as I am, this is how I feel, this is who I am', is exactly what is meant by an unethical stance. 
For Foer, human beings are capable of telling new and more ethical stories about themselves and the world, transforming, in the meantime, the unethical into the ethical. To illustrate, Foer points out the irony of the Thanks giving story, which is the distinctly American story of "conscientious consumption" or "ethical consumerism," yet what is consumed at the Thanks giving dinner is factory farmed, that is, genetically modified, cruelly constrained, mutant turkeys (Foer, 2009, 266). He suggests that each American can start by rethinking the Thanks giving story; each Jew can rethink what the moral mandate of the kosher really means. As his grandmother said, there must be circumstances under which one cannot eat pork (unkosher meat) even to save one's life; there must be circumstances under which it must be unethical to eat cruelly produced food. Otherwise there would not be anything to save. Foer, accepting that the factory farm is "inhuman," feels that he would "not be himself" any more if he "walked away in the face of such suffering" (Foer, 2009, 267). And socially, our communal response to the factory farm is ultimately "a test" of how we "respond" to the suffering and the fate of the "powerless, the most distant, the voiceless it is a test of how we act when no one is forcing us to act one way or another" (Foer, 2009, 266). As Foer reminds us, Martin Luther King Jr. insists that "one must take a position that is neither safe, nor politic, nor popular" (qtd. in Foer, 2009, 258). It is our "conscience" that will tell us what that position should be (Foer, 2009, 259). In the process, we can use our ability to tell new stories, truly ethical stories, as Foer does in Eating Animals.

\section{Conclusion}

For Foer, our dietary habits are essentially ethical problems in that they define us: "The question of eating animals is ultimately driven by intuitions about what it means to reach an ideal we have named, perhaps incorrectly, 'being human"' (Foer, 2009, 264). The driving force of his quest is quite personal, but undeniably human, and universal: how can we attain moral integrity while at the same time facing reality and responding ethically, and how can we pass on valid morals to our children? As much as Foer relies on investigative journalism to learn and expose, he also undertakes a discussion of the human in its ethical bearing that is inherently connected to the stories we tell ourselves, the stories through which we create our selves. In this sense, Foer offers revitalizing opportunities for the American writer who is open to a rigorous, meticulous, and extensive discussion and analysis of contemporary but timeless issues that define the human.

To conclude, Foer shows that our ethical response to the circumstances of modern-day meat production is nothing but the trial of our humanity, our ethics, another instance of the self's struggle with its desires and emotions, and the other. Therefore, when subjected to ethical criticism an endeavor that suffers from a curious lack of interest in nonfiction, Foer's text itself emerges as the unknown other that we have to encounter, respond ethically, and redefine ourselves in our response to it. Indeed, the human in Foer's book is an animal that eats hence the eating animals of the title and the human should be ethically responsible for every deed-hence, again, the eating animals of the title. Obliged, reminded, and urged to think more thoroughly and responsibly about ethical life, Foer undertakes a nonfictional quest into the moral realm of storytelling and the reader, confronting herself as the other, confronting the animal as the other, is invited to lead a more ethical life. 


\section{REFERENCES}

Booth, W. (1988). The Company We Keep: An Ethics of Fiction. Los Angeles: University of California Press.

Buell, L. (1999). "In Pursuit of Ethics". PMLA, Spec. Issue Ethics and Literary Study, 114 (1), 7-19.

Davis, Todd, \& Kenneth Womack. Eds. (2001). Mapping the Ethical Turn: A Reader in Ethics, Culture, and Literary Theory. Charlottesville: The University Press of Virginia.

Eskin, M. (2004). “The Double 'Turn' to Ethics and Literature?”. Poetics Today, 25 (4), 557-572.

Foer, J. S. (2009). Eating Animals. London: Penguin.

Geddes, J. (2007). "Attending to suffering in/at the Wake of Postmodernism". Eds. Neil Brooks, \& Josh Toth. The Mourning After: Attending the Wake of Postmodernism, 65-79. Amsterdam: Rodopi.

Hale, D. J. (2007). "Fiction as Restriction: Self-Binding in New Ethical Theories of the Novel". Narrative, 15 (2), 187-206.

Harpham, G. G. (1995). "Ethics". Eds. Frank Lentricchia, \& Robert McLaughlin. Critical Terms for Literary Study: 387-405. Baltimore: Johns Hopkins University Press.

Marjorie, G., Hanssen, B., \& Walkowitz, R. L. Eds. (2000). The Turn to Ethics. New York: Routledge.

Nussbaum, M. C. (1990). Love's Knowledge: Essays on Philosophy and Literature. Oxford: Oxford University Press.

Schwarz, D. R. (2001). "A Humanistic Ethics of Reading". Eds. Todd Davis, \& Kenneth Womack. Mapping the ethical Turn: A Reader in Ethics, Culture, And Literary Theory, 3-16. Charlottesville: The University Press of Virginia.

Schwarz, D. R. (1997). "Performative Saying and the Ethics of Reading: Adam Zachary Newton's Narrative Ethics". Narrative, 5 (2), 188-206.

Voloshin, B. R. (1998). "The Ethical Turn in French Philosophy". Pacific Coast Philology, 33 (1), 69-86. 